\title{
THE DETERMINATION OF MAGNESIA IN PHOSPHATE ROCK
}

\author{
By James I. Hoffman
}

\section{ABSTRACT}

A method for the determination of magnesia in phosphate rock is presented. Calcium is separated as sulphate in alcoholic solution, and magnesium is determined in the filtrate by precipitating it as magnesium ammonium phosphate. Citric acid is added to prevent interference by iron, aluminum, and titanium. In this procedure part of the manganese always accompanies the magnesium. This is determined in the ignited residue by the periodate method. The data show that arsenic does not interfere and that the method is also applicable if larger amounts of magnesium are present than are usually found in phosphate rock.

\section{CONTENTS}

Page

I. Introduction

II. Method for the determination of magnesia. 488

III. Discussion of the method

1. Decomposition of the sample 490

2. Separation of calcium sulphate by means of alcohol_.... 490

3. Precipitating magnesium as magnesium ammonium phos-

IV. Acknowledgment.

\section{INTRODUCTION}

Practically all samples of phosphate rock contain less than 0.5 per cent of magnesia. To determine this a procedure must be used in which large amounts of calcium and moderate amounts of iron, aluminum, titanium, manganese, and fluorine are eliminated. Calcium can be separated by precipitating it as oxalate in an oxalic acid solution, ${ }^{1}$ or as sulphate in an alcoholic solution. If the former procedure is used, the precipitation with oxalate must be repeated. Precipitating calcium as sulphate is more suitable in this case because the separation of small amounts of magnesium is so nearly complete in a single precipitation that the operation need not be repeated. Iron, aluminum, titanium, and part of the manganese are eliminated if magnesium is precipitated as magnesium ammonium phosphate in a solution containing ammonium citrate, and a correction for any manganese which is precipitated can be applied to the finally weighed residue. Fluorine is eliminated at the start by evaporating with sulphuric acid. Arsenic, if it is not previously eliminated, is volatilized during the evaporation of the alcohol after the calcium sulphate is separated.

The following method was found to yield satisfactory results when applied to synthetic mixtures and to the Bureau of Standards

1 G. E. F. Lundell and J. I. Hoffman, The Analysis of Phosphate Rock, J. Assoc. Official Agric. Chem. vol. 8 , p. 184, 1924 .

$137718-32-3$ 
standard sample of phosphate rock, No. 56, which has the following percentage composition: $\mathrm{P}_{2} \mathrm{O}_{5}, 31.3 ; \mathrm{Fe}_{2} \mathrm{O}_{3}, 3.3 ; \mathrm{Al}_{2} \mathrm{O}_{3}, 3.1 ; \mathrm{CaO}, 44.8$; $\mathrm{SiO}_{2}, 6.7 ; \mathrm{TiO}_{2}, 0.15 ; \mathrm{MnO}, 0.25 ; \mathrm{MgO}, 0.32 ; \mathrm{F}, 3.6$. This composition is typical of phosphate rocks excepting that in most cases smaller percentages of the oxides of manganese and magnesium are present.

\section{METHOD FOR THE DETERMINATION OF MAGNESIA}

Transfer $2 \mathrm{~g}$ of phosphate rock, ground to pass a No. 100 sieve and dried for one hour at $105^{\circ} \mathrm{C}$., to a $250 \mathrm{ml}$ beaker, cover, add $15 \mathrm{ml}$ of diluted hydrochloric acid $(2+1)^{2}$ and $5 \mathrm{ml}$ of nitric acid, and boil gently for 10 to 15 minutes. Remove the beaker from the source of heat, add $6 \mathrm{ml}$ of diluted sulphuric acid $(1+1)$, remove the cover, and evaporate until fumes of sulphuric acid appear. Cool slightly, wash down the inside surface of the beaker with a jet of water and again evaporate until fumes of sulphuric acid appear. Cool, add $10 \mathrm{ml}$ of water, stir thoroughly, and digest on the steam bath for 10 to 15 minutes. Remove from the steam bath, add $100 \mathrm{ml}$ of 95 per cent alcohol, ${ }^{3}$ stir so that the calcium sulphate is well dispersed throughout the liquid, and then allow to stand for 30 minutes or longer. Filter by means of suction through a tight plug of filter paper pulp, using a Gooch crucible, carbon funnel, or Büchner funnel, and wash five times with $5 \mathrm{ml}$ portions of 95 per cent alcohol containing $1 \mathrm{ml}$ of sulphuric acid per $100 \mathrm{ml}$.

Evaporate the alcoholic filtrate as far as possible on the steam bath. Transfer the solution to a $300 \mathrm{ml}$ Erlenmeyer flask, dilute to 75 to $100 \mathrm{ml}$, and add $2 \mathrm{~g}$ of citric acid and $15 \mathrm{ml}$ of a 25 per cent solution of diammonium phosphate, $\left(\mathrm{NH}_{4}\right)_{2} \mathrm{HPO}_{4}$. Add ammonium hydroxide until the solution is alkaline to litmus and then add $10 \mathrm{ml}$ in excess. Add 5 to 10 glass beads, tightly stopper the flask, and shake on a shaking machine for at least one hour. Allow to stand in a cool place for four hours or preferably overnight. Filter through a tight paper containing a little paper pulp, and wash with diluted ammonium hydroxide $(5+95)$, containing $50 \mathrm{~g}$ of diammonium phosphate per liter, until the precipitate and paper are free from iron and aluminum. Pass $25 \mathrm{ml}$ of hot diluted hydrochloric acid $(5+95)$ through the paper into the flask, transfer the solution to a $150 \mathrm{ml}$ beaker, and wash the paper and flask thoroughly with more of the diluted acid. To the solution in a volume of 50 to $75 \mathrm{ml}$ and containing no glass beads, add $1 / 2 \mathrm{ml}$ of a 25 per cent solution of diammonium phosphate, cool, and then add ammonium hydroxide slowly and with stirring until the solution is alkaline to litmus. Stir for a few minutes, then add 3 to $4 \mathrm{ml}$ of ammonium hydroxide and allow to stand for four hours or overnight. Transfer the precipitate to a small filter and wash with diluted ammonium hydroxide $(5+95)$. Transfer the paper and precipitate to a platinum crucible, ignite slowly at a temperature below $900^{\circ} \mathrm{C}$. until the carbon is burned (preferably in a muffle furnace with pyrometric control), and then at about $1,100^{\circ}$ C. for one to two hours. Cool and weigh.

2 This denotes 2 volumes of hydrochloric acid, specific gravity 1.18 , mixed with 1 volume of water. This system of designating the diluted acids or ammonium hydroxide is used throughout this paper. If no system of designating the diluted acids or ammonium hydr
dilution is specified, the concentrated reagent is intended.

3 In most of this work 95 per cent ethyl alcohol was used. Mixtures of 100 parts of 95 per cent ethyl alcohol with from 5 to 25 parts of methyl alcohol proved equally satisfactory. 
The residue consists of $\mathrm{Mg}_{2} \mathrm{P}_{2} \mathrm{O}_{7}$ and possibly $\mathrm{Mn}_{2} \mathrm{P}_{2} \mathrm{O}_{7}$ and $\mathrm{Ca}_{3}$ $\left(\mathrm{PO}_{4}\right)_{2}$. If the alcoholic filtrate was clear, the tricalcium phosphate, $\mathrm{Ca}_{3}\left(\mathrm{PO}_{4}\right)_{2}$, will not exceed $0.3 \mathrm{mg}$ and can be neglected unless very accurate results are desired. ${ }^{4}$ The correction for manganese is made as follows: Dissolve the residue in $10 \mathrm{ml}$ of diluted sulphuric acid $(1+9)$, transfer the solution to a $300 \mathrm{ml}$ Erlenmeyer flask, and add $50 \mathrm{ml}$ of diluted nitric acid $(1+3), 2 \mathrm{ml}$ of sirupy phosphoric acid, specific gravity, 1.7 , and $0.2 \mathrm{~g}$ of potassium periodate, $\mathrm{KIO}_{4}$. Boil for 15 to 20 minutes, cool, and dilute to a convenient volume. In another flask containing the same amounts of the reagents treated in a similar way, match the color by adding a standard solution of potassium permanganate. From the volume of the solution of permanganate required, calculate the weight of $\mathrm{Mn}_{2} \mathrm{P}_{2} \mathrm{O}_{7}$ in the residue Subtract this weight from the total weight, and regard the difference as $\mathrm{Mg}_{2} \mathrm{P}_{2} \mathrm{O}_{7}$, which contains 36.21 per cent of $\mathrm{MgO}$.

Table 1 gives results obtained by this method for magnesia in phosphate rock and in mixtures approximating the composition of phosphate rock. The standard value for magnesia ( 0.32 per cent) in the Bureau of Standards standard sample of phosphate rock, No. 56, was obtained by twice precipitating the calcium as oxalate in dilute oxalic acid solution ${ }^{5}$ and determining the magnesia in the combined filtrates by precipitating as magnesium ammonium phosphate in the presence of ammonium citrate and then igniting to magnesium pyrophosphate. Corrections were made for calcium and manganese.

TABLE 1.-Results obtained for magnesia in phosphate rock and in synthetic mixtures

\begin{tabular}{|c|c|c|c|c|c|c|}
\hline $\begin{array}{c}\text { Analysis } \\
\text { No. }\end{array}$ & Material analyzed & $\begin{array}{c}\text { Mgo } \\
\text { present } \\
\text { or add- } \\
\text { ed }\end{array}$ & $\begin{array}{l}\mathrm{MgO} \\
\text { found }\end{array}$ & $\begin{array}{c}\mathrm{MgO} \\
\text { present } \\
\text { or add- } \\
\text { ed }\end{array}$ & $\begin{array}{l}\text { MgO } \\
\text { found }\end{array}$ & Error \\
\hline & $0.12 \mathrm{~g} \mathrm{Fe}_{2} \mathrm{O}_{3}+0.12 \mathrm{~g} \mathrm{Al}_{2} \mathrm{O}_{3}+0.1 \mathrm{~g} \mathrm{CaF}_{2}+1.65 \mathrm{~g} \mathrm{Ca}_{3}$ & \multirow{8}{*}{$\begin{array}{c}g \\
0.0008 \\
.0008 \\
.0032 \\
.0079 \\
.1140 \\
.0032 \\
.0032 \\
.0079\end{array}$} & \multirow{5}{*}{$\begin{array}{r}g \\
0.0007 \\
.0008 \\
.0031 \\
.0078 \\
.1130\end{array}$} & \multirow{5}{*}{$\begin{array}{c}\text { Per cent } \\
0.04 \\
.04 \\
.16 \\
.395 \\
5.70\end{array}$} & \multirow{5}{*}{$\begin{array}{c}\text { Per cent } \\
0.035 \\
.04 \\
.155 \\
.40 \\
5.65\end{array}$} & \multirow{5}{*}{$\begin{array}{r}\text { Percent } \\
-0.005 \\
.000 \\
-.005 \\
+.005 \\
-.05\end{array}$} \\
\hline & - & & & & & \\
\hline & -.do.. & & & & & \\
\hline & -.do & & & & & \\
\hline & $0.12 \mathrm{Fe}_{2} \mathrm{O}_{3}+0.12 \mathrm{~g}$ & & & & & \\
\hline & $+1.65 \mathrm{~g} \mathrm{Ca}_{3}\left(\mathrm{PO}_{4}\right)_{2}$ & & .0034 & .16 & .17 & +.01 \\
\hline & $0.12 \mathrm{~g} \mathrm{Fe}_{2} \mathrm{O}_{3}+0.12 \mathrm{~g} \mathrm{Al}_{2} \mathrm{O}_{3}+0.1 \mathrm{~g} \mathrm{CaF}_{2}+0.0045 \mathrm{~g} \mathrm{MnO}^{-}$ & & & . 166 & & \\
\hline & 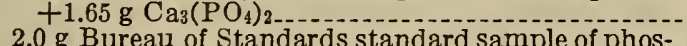 & & .00 & .395 & .395 & .000 \\
\hline & phate rock No. 56....................... & & & .32 & .32 & .00 \\
\hline & $--d a$ & & & 3 & $.3 i$ & \pm .01 \\
\hline & ample of phos- & & & & & \\
\hline 13. & d sample of phos- & & & .78 & .79 & 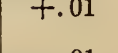 \\
\hline & phate & & & .32 & .31 & -.01 \\
\hline
\end{tabular}

1 If a correction for calcium is to be made, dissolve the residue in $10 \mathrm{ml}$ of diluted sulphuric acid (5+95), evaporate to about $5 \mathrm{ml}$, and then add $25 \mathrm{ml}$ of 95 per cent alcohol. Allow to stand for one to two hours, filter on a small paper, and wash with alcohol. Dry the paper in the funnel and dissolve the precipitate of calcium sulphate in $20 \mathrm{ml}$ of hot diluted hydrochloric acid (1+99). Add a few crystals of ammonium oxalate, heat, render the solution faintly ammoniacal, and allow to stand for one-half to one hour. Filter, ignite, and weigh as $\mathrm{CaO}$. Calculate to tricalcium phosphate, $\mathrm{Ca}_{3}\left(\mathrm{PO}_{4}\right)_{2}$, and subtract from the apparent weight of $\mathrm{Mg}_{2} \mathrm{P}_{2} \mathrm{O}_{7}$.

If calcium is determined in this way, the alcoholic filtrate is used for the determination of manganese. Before applying the periodate oxidation, this filtrate must be evaporated and heated until fumes of sulphuric acid appear, and then treated with nitric acid to make sure that reducing substances are absent.

See The Analysis of Phosphate Rock, J. Assoc. Official Agric. Chem., vol. 8, p. 203; 1924. 
The magnesium that was used in making up the mixtures was added in the form of a standard solution of magnesium chloride. The iron and aluminum were added as solutions of their chlorides. The Bureau of Standards standard sample of fluorspar No. 79 was used as the source of the $\mathrm{CaF}_{2}$ added. The percentage composition of this sample is: $\mathrm{CaF}_{2}, 94.8 ; \mathrm{CaCO}_{3}, 2.17 ; \mathrm{SiO}_{2}, 1.9 ; \mathrm{Zn}, 0.35 ; \mathrm{Pb}, 0.23 ; \mathrm{S}, 0.13$; $\mathrm{Fe}_{2} \mathrm{O}_{3}, 0.15 ; \mathrm{Al}_{2} \mathrm{O}_{3}, 0.02 ; \mathrm{MgO}, 0.13$. The tricalcium phosphate that was used contained $0.3 \mathrm{mg}$ of $\mathrm{MgO}$ in $1.65 \mathrm{~g}$. Proper corrections were made for the magnesia thus introduced.

The calcium sulphate obtained by precipitation with alcohol in analysis No. 5 was dissolved in hot hydrochloric acid and then evaporated with $6 \mathrm{ml}$ of diluted sulphuric acid $(1+1)$. The precipitation by alcohol was repeated and the magnesia determined in the filtrate as before. The amount of $\mathrm{MgO}$ found was $0.0011 \mathrm{~g}$. This indicates that if large amounts of magnesium are present, some is retained by the calcium sulphate. Less than 0.005 per cent of $\mathrm{MgO}$ was retained by the calcium sulphate in the case of phosphate rock No. 56 (analyses Nos. 9 to 13).

\section{DISCUSSION OF THE METHOD}

\section{DECOMPOSITION OF THE SAMPLE}

A $2 \mathrm{~g}$ sample each of Tennessee brown rock ( $\mathrm{MgO}-0.02$ per cent), Tennessee blue rock ( $\mathrm{MgO}-0.36$ per cent), Florida pebble rock ( $\mathrm{MgO}-0.25$ per cent), Florida hard rock $(\mathrm{MgO}-0.05$ per cent), Wyoming phosphate rock $(\mathrm{MgO}-0.08$ per cent) and Idaho phosphate rock $\left(\mathrm{MgO}-0.31\right.$ per cent) ${ }^{6}$ was decomposed by treatment with hydrochloric and nitric acids as described in the preceding section. The following test was made to determine the amount of magnesia in the insoluble residue: After adding $50 \mathrm{ml}$ of water and digesting, the insoluble matter was collected on a filter, washed, and ignited in platinum. The ignited residue was brought into solution by treating with hydrofluoric and sulphuric acids and then evaporating until fumes of sulphuric acid were copiously evolved. The contents of the crucible were transferred to a small beaker by means of 25 to $30 \mathrm{ml}$ of 95 per cent alcohol, and the calcium sulphate which separated was removed by filtration. Magnesium was determined in the filtrate by the method above outlined for the determination of magnesia in phosphate rock. An average of less than 0.005 per cent of magnesia, $\mathrm{MgO}$, was found in the insoluble matter, and in no case did the percentage exceed 0.01 .

\section{SEPARATION OF CALCIUM SULPHATE BY MEANS OF ALCOHOL}

The results in the table show that the separation of calcium sulphate by means of alcohol is very satisfactory for the small amounts of magnesium present in phosphate rock and that it is applicable even if much larger amounts are involved. The amount of sulphuric acid specified is the minimum that should be used, because if the sulphates become dry and form a cake during the evaporation with sulphuric acid, it is difficult to extract all of the magnesium with

${ }^{6}$ These representative samples were furnished through the courtesy of $\mathrm{K}$. D. Jacob, of the United States Department of Agriculture. 
alcohol. There is less danger of calcium sulphate running through the filter if a little sulphuric acid is added to the alcohol used for washing and if the filter is not allowed to run dry. The presence of considerable amounts of organic matter, such as are found in some samples of phosphate rock, does not adversely affect the separation.

\section{PRECIPITATING MAGNESIUM AS MAGNESIUM AMMONIUM PHOSPHATE}

In order to avoid tedious separations, it is desirable to precipitate the magnesium in the presence of the iron and aluminum. About $2 \mathrm{~g}$ of citric acid must be added to hold in solution the amounts of these elements that may be expected in phosphate rock. In such solutions it is difficult to precipitate small amounts of magnesium ammonium phosphate. In some cases complete precipitation is not obtained even if the solution is vigorously stirred or shaken mechanically, but if the solution is shaken in a flask containing a few glass beads, complete precipitation can readily be had. The precipitate thus obtained is very finely divided, which necessitates the use of a very tight filter. The most satisfactory filtering medium consists of a tight paper containing some fine paper pulp. Glass beads are not used in the second precipitation.

If small amounts of magnesium, such as are likely to be encountered in phosphate rock, are precipitated as magnesium ammonium phosphate in the presence of ammonium citrate without agitation, a few hours are sometimes required before the crystals begin to separate. These transparent crystals adhere to the beaker and stirring rod and are slightly soluble in the ordinary wash solutions. If they are broken in transferring them to the paper, more will dissolve in the wash water than if they remain undisturbed.

If manganese is present in a solution in which magnesium ammonium phosphate is precipitated, it is quantitatively precipitated under the usual conditions such as are outlined for the last precipitation, but if citric acid is added, as in the first precipitation, less than onethird of the manganese accompanies the magnesium when the two are present in the proportions usually found in phosphate rock. This quantity is not constant, and it is necessary to determine the manganese in the ignited residue that is finally obtained. If it is known that the phosphate rock contains less than 0.02 per cent of manganese oxide (MnO), the correction may be neglected.

\section{ACKNOWLEDGMENT}

Acknowledgment is made to Dr. G. E. F. Lundell for technical advice.

Washington, July 6, 1932. 